\title{
Minerals and speleothems of the József-hegy Cave (Budapest, Hungary).
}

\author{
Szabolcs Leél-Őssy ${ }^{1}$, Gyöngyvér Szanyi² and Gergely Surányi ${ }^{3}$
}

\begin{abstract}
:
Leél-Őssy S., Szanyi G. and Surányi G. 2011. Minerals and speleothems of the József-hegy Cave (Budapest, Hungary). International Journal of Speleology, 40 (2), 191-203. Tampa, FL (USA). ISSN 0392-6672. DOI 10.5038/1827-806X.40.2.11

With the discovery of the József-hegy Cave, a cave of hydrothermal origin with an abundance of minerals unknown so far in Hungary came to light. Diversity and the frequency of the occurrence of crystals make this cave similar to the Lechuguilla Cave, even if the dimensions of the mineral precipitations and the passages do not compare in scale. The variety and mass of carbonates and sulphates are surprising. This paper describes the minerals and speleothems of the József-hegy Cave, their occurrence and genesis, including determined ages. The $41 \mathrm{U} /$ Th measurements suggest that speleothems begun to develop in the upper level of the cave more than $350 \mathrm{ka}$ ago. Some of these dated old speleothems were developing in dry passages, thus the uppermost passages of the József-hegy Cave have been dry at least for 350 ka. The karst water level was still at the main passage 200 ka ago and dropped to $120 \mathrm{~m}$ asl by the time of $\sim 100$ ka before present.
\end{abstract}

Keywords: thermal karst cave, cave minerals, U/Th age, Budapest, József-hegy Cave

Received 4 January 2011; Revised; 13 May 2011; Accepted 22 May 2011

\section{INTRODUCTION}

Budapest, the capital of Hungary is famous for its thermal springs and spas. The ascending thermal water dissolved many cave passages near the surface, close to the karstwater table. The first cave discoveries happened at the beginning of the 20th century, when the limestone quarries were operating in the Buda Hills. The thermal karstic caves are situated under Rózsadomb, the most exclusive part of the city (Fig. 1). Ottokár Kadić, one of the greatest speleologists in Hungary, called Budapest 'the capital of the caves' almost 100 years ago. At this moment, more than 100 caves are known in the $5-6 \mathrm{~km}^{2}$ territory of Rózsadomb, their total length exceeds 45 $\mathrm{km}$ (Leél-Össy, 2010). Six of them is longer than two kilometres. The corridors are sometimes more than 100 metres in length, and spherical niches often decorate their walls. These caves are typical examples

\footnotetext{
${ }^{1}$ Eötvös Loránd University, Department of Physical and Historical Geology, 1117 Budapest, Pázmány Péter sétány 1/C, Hungary (losz@geology.elte.hu)

${ }^{2}$ HAS Geodetic and Geophysical Research Institute, Seismological Observatory, 1112 Budapest, Meredek u. 18., Hungary

${ }^{3}$ HAS Geological, Geophysical and Space Science Research Group, 1117 Budapest, Pázmány Péter sétány 1/C, Hungary
}

of the thermal water origin (Müller \& Sárváry, 1977; Kovács \& Müller, 1980; Takácsné Bolner, 1989; Takácsné Bolner \& Kraus, 1989; Nádor, 1992; Ford, 1995; Dublyansky, 1995), just like the caves of the Black Hills (Bakalowicz et al., 1987). Their genesis is interpreted as a result of mixing corrosion along the tectonic fractures at the level of karstwater table.

Amongst them, the József-hegy Cave (Fig. 2), discovered by the members of the Kinizsi Cave Research Group of Rózsadomb under the guidance of Szabolcs Leél-Ốssy and Péter Adamkó in 1984, is by far the richest in mineral precipitations.

In the last decades, several studies have been written on the genesis and the minerals of the caves in the area (e.g. Jaskó, 1936; Jakucs, 1948, 1994; Kessler, 1957; Leél-Őssy, 1957; Müller \& Sárváry, 1977; Kovács \& Müller, 1980; Gatter, 1984; TakácsnéBolner \& Kraus, 1989; Fodor et al., 1991; Kraus, 1991; Nádor, 1992; Adamkó et al., 1992; Dublyansky, 1995, 2000; Ford \& Takácsné-Bolner, 1992; Kleb et al., 1993; Ford, 1995; Leél-Őssy \& Surányi, 2003; Leél-Őssy, 2010). However, no mineralogical study was performed focusing on the József-hegy Cave until now. In Hungary, every cave is a nature conservation area. Some of them are open to the public, but the József-hegy Cave is strictly protected: only a few researchers can visit it. The aim of this paper is to introduce the cave's mineral associations to the scientific and public community. 


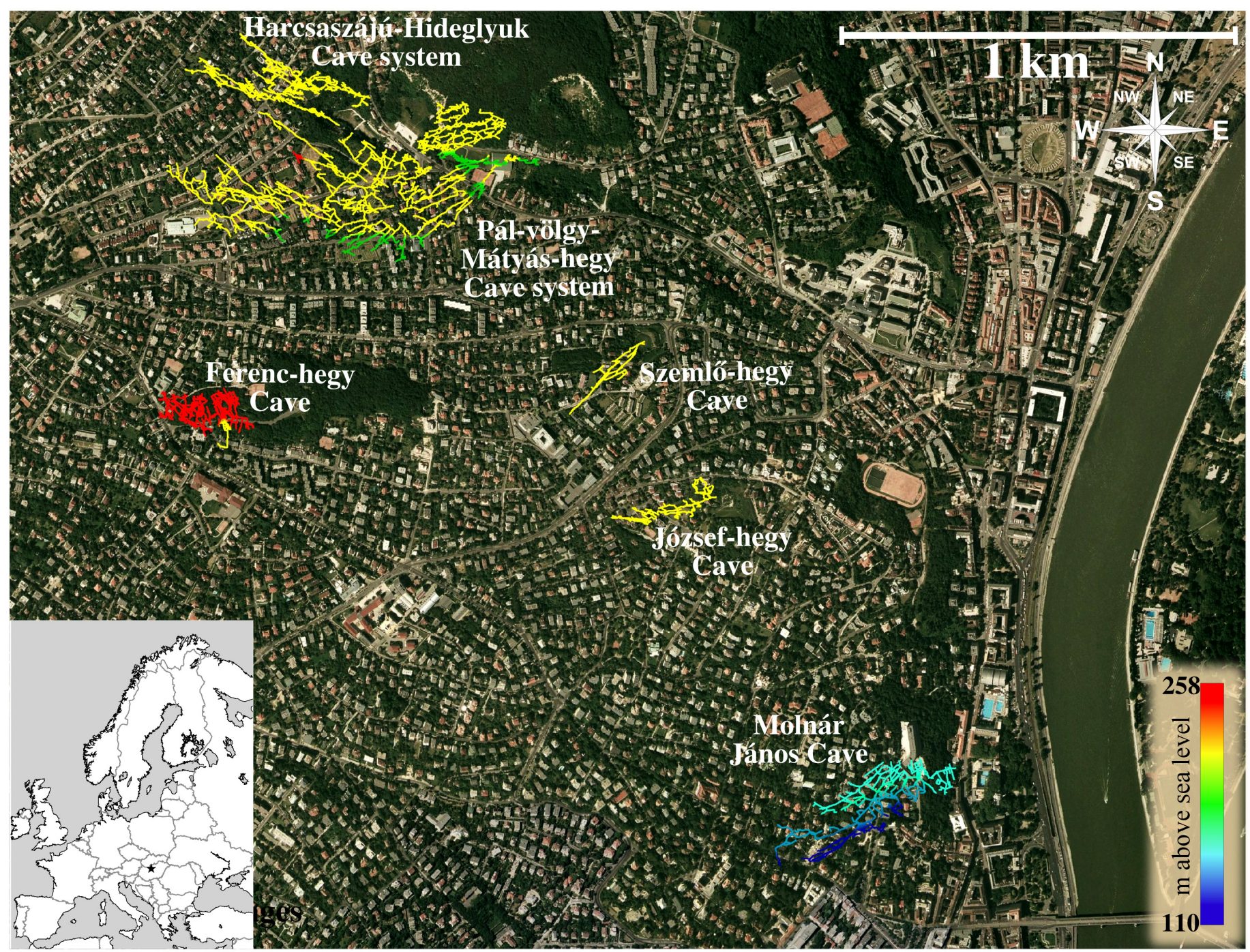

Fig. 1. Location of major caves in the Rózsadomb area, Budapest. The inset shows the position of the investigated region on the map of Europe and Hungary, respectively.

The exceptional values of this cave are the more than a dozen species of minerals. Especially the variety and mass of carbonates and sulphates are remarkable. Minerals precipitated from warm water and vapour along with present day mineral deposition from cold water origin are equally common.

\section{GEOLOGICAL SETTING}

The Buda Hills consist of karstifiable rocks, mainly of limestone and dolomite (Fig. 3). The age of the oldest known rock is Upper Triassic in this territory (Horusitzky, 1939; Wein, 1977). There are two Triassic formations in the Rózsadomb area: the Mátyáshegy Formation (it consists of dolomite and limestone, but from the Józsefhegy Cave a highly marly facies is also known) and the Main Dolomite Formation. The age of the Mátyáshegy Formation is Carnian-NorianRhaetian (Kozur \& Mock, 1991). The thickness of this cherty formation is only 50-200 m (Haas, 1993). This formation is intensely karstified. The age of the Main Dolomite is Carnian-Norian. In this unit, caves are very rare. The thickness of this formation is $1500-2000 \mathrm{~m}$ (Haas, 1993). This rock is strongly friable at many places.
The Triassic formations are covered by Paleogene and Quaternary formations. Thus, there is a more than 150 million-year-long hiatus in the sequence (Horusitzky, 1939).

The first products of the Upper Eocene are the few metres thick beds of basal conglomerate (Fodor et al., 1994). The age of the covering Szépvölgy Limestone Formation is also Upper Eocene. The thickness of this formation is up to several tens of metres. The caves of Rózsadomb were developed mainly in this rock.

The Szépvölgy Limestone Formation is usually covered by the Upper Eocene-Lower Oligocene Buda Marl Formation. The thickness of this formation is less than $100 \mathrm{~m}$ in Rózsadomb, and it is mostly known from caves and boreholes. The Buda Marl always has considerable clay content; therefore, it is poorly karstifiable. However, several cave corridors are in these beds in the József-hegy Cave (Adamkó et al., 1992). This lowest part of the Buda Marl, where some caves can be found, is called 'bryozoan marl'. There are allodapic limestone layers interbedded into the marl, which can also be seen at the entrance of the József-hegy Cave. Some tuff horizons can be also found, which suggests that volcanism was present at the time of accumulation of the Buda Marl Formation (Báldi, 1986). 


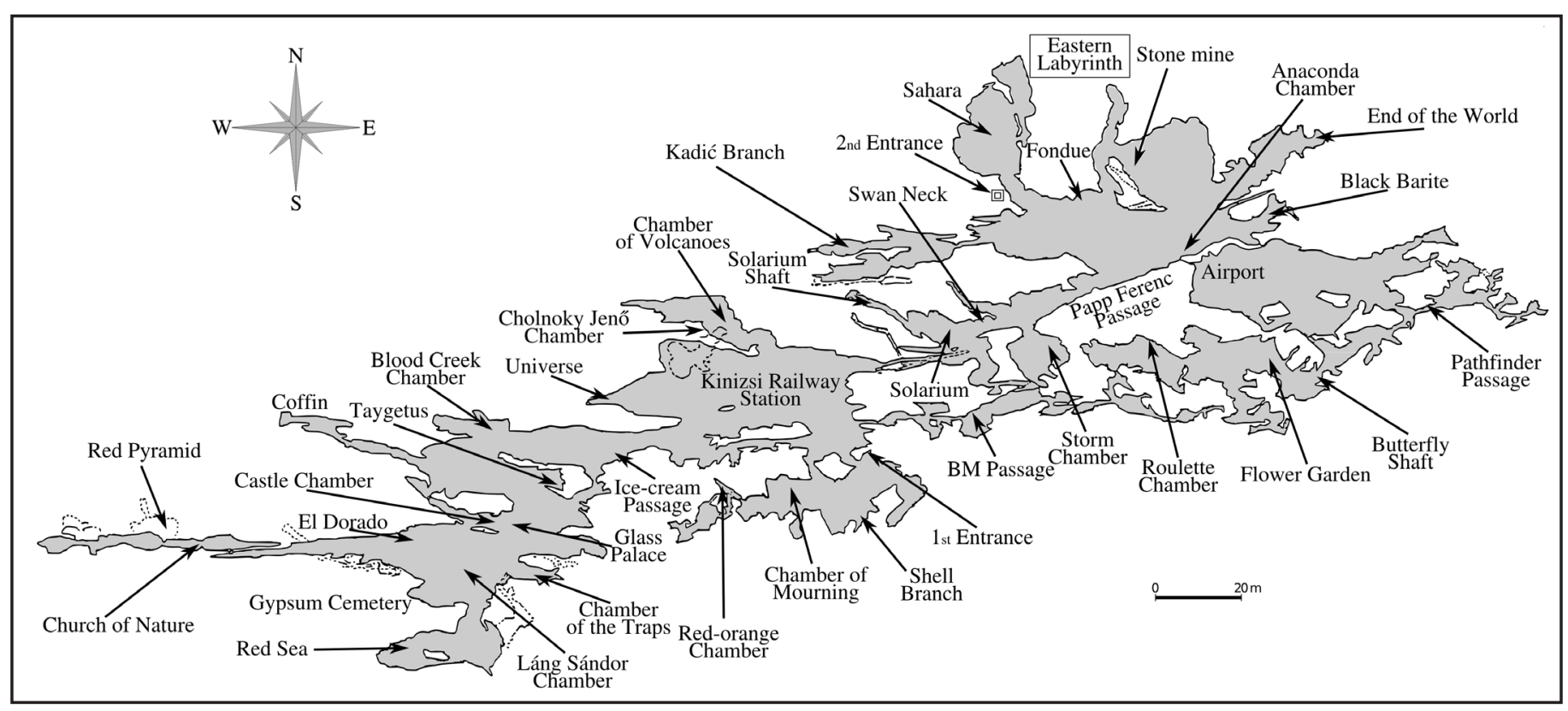

Fig. 2. The map of József-hegy Cave with passage names, used in the text.

At the surroundings of the József-hegy Cave other Tertiary rocks are known (e.g. the Tard Clay and the Kiscell Clay). These are devoid of caves. Andesite volcanic activity took place during the Badenien (15 Ma ago), $20 \mathrm{~km}$ away from Rózsadomb to the north. There are no volcanic rocks related to this episode in the Buda Hills, but it is possible that the formation of barite veins are somehow related to this volcanism.

Freshwater limestone of Pleistocene-Holocene age occurs at the surface (Scheuer \& Schweitzer, 1988) at many places between 160 and $220 \mathrm{~m}$ asl.

Passages of the József-hegy Cave are hosted in Triassic and Eocene carbonate sequences (Fig. 3), mostly in the Szépvölgy Limestone Formation. Some galleries and most of the smaller (less than $2 \mathrm{~m}$ in diameter), separate spherical niches are also hosted by the Buda Marl Formation. The lowest galleries of some caves extend into the Triassic carbonate sequence. The cave passages were dissolved along tectonic fissures (Fodor et al., 1991).

\section{METHODS}

The authors used the results of the thin-section analyses and inclusion examinations carried out by Gatter (1984) and the result of the X-ray power diffraction by Kleb et al. (1993). The U-series disequilibrium age determinations were accomplished during two measurement periods. First, in 1996, Leél-Össy executed a thorough alpha spectrometric dating at the University of Bergen, Norway, in the laboratory of Stein-Erik Lauritzen. More than 10 years later, in 2007 , the authors had the opportunity to continue this dating using ICP-MS measurements for age determination. The basis of the used chemical process and the age calculation method was developed by Surányi (2005) and further modified by the authors. The errors of the ages were calculated using the Monte Carlo method. Measurement errors, background noise, solvation, mass bias, and the effect of the isotopes in the spiking solution were taken into

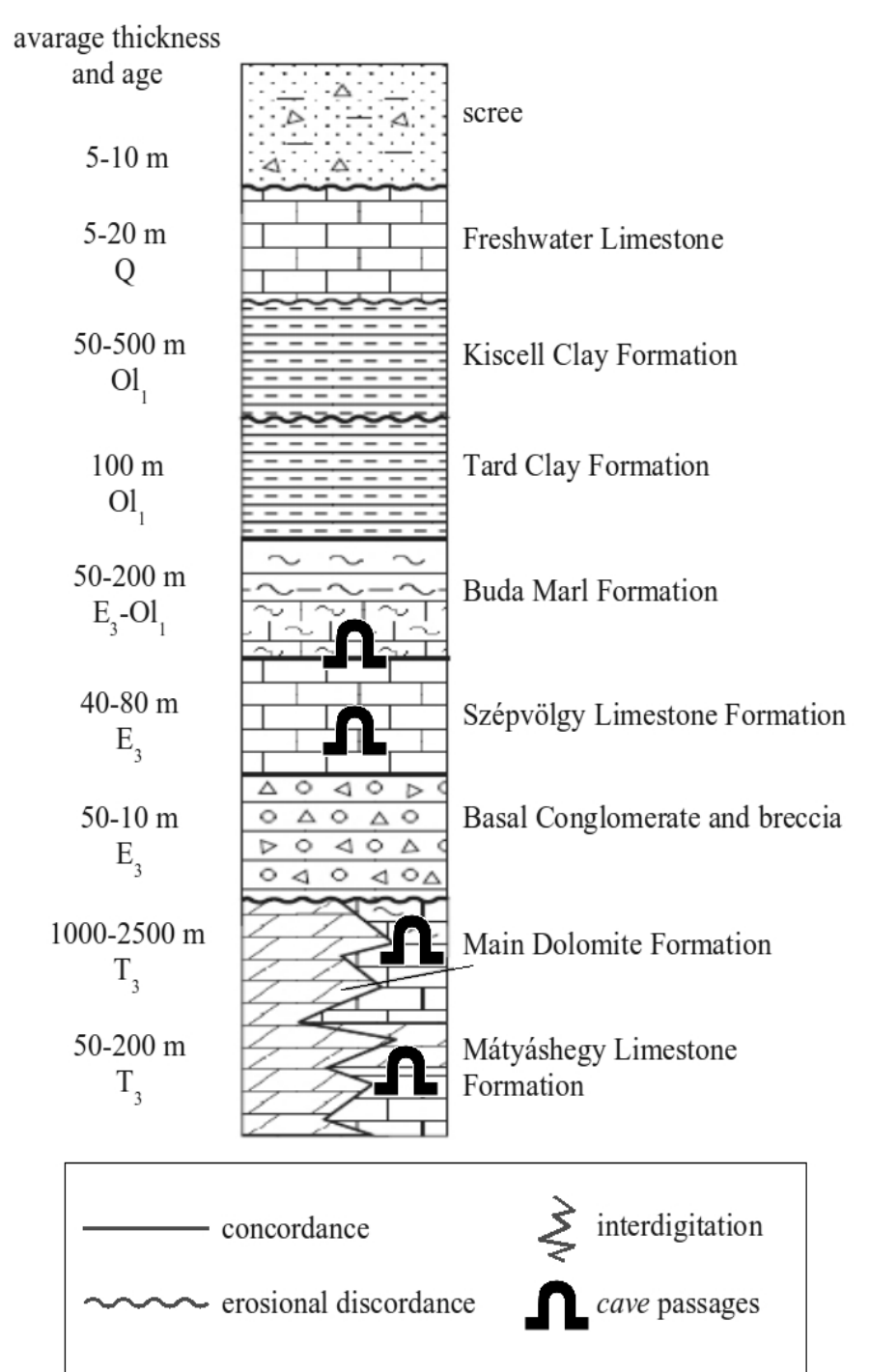

Fig. 3. Lithostratigraphic column of the Rózsadomb area with localization of cave passages of the József-hegy Cave (after LeélŐssy \& Surányi, 2003). 


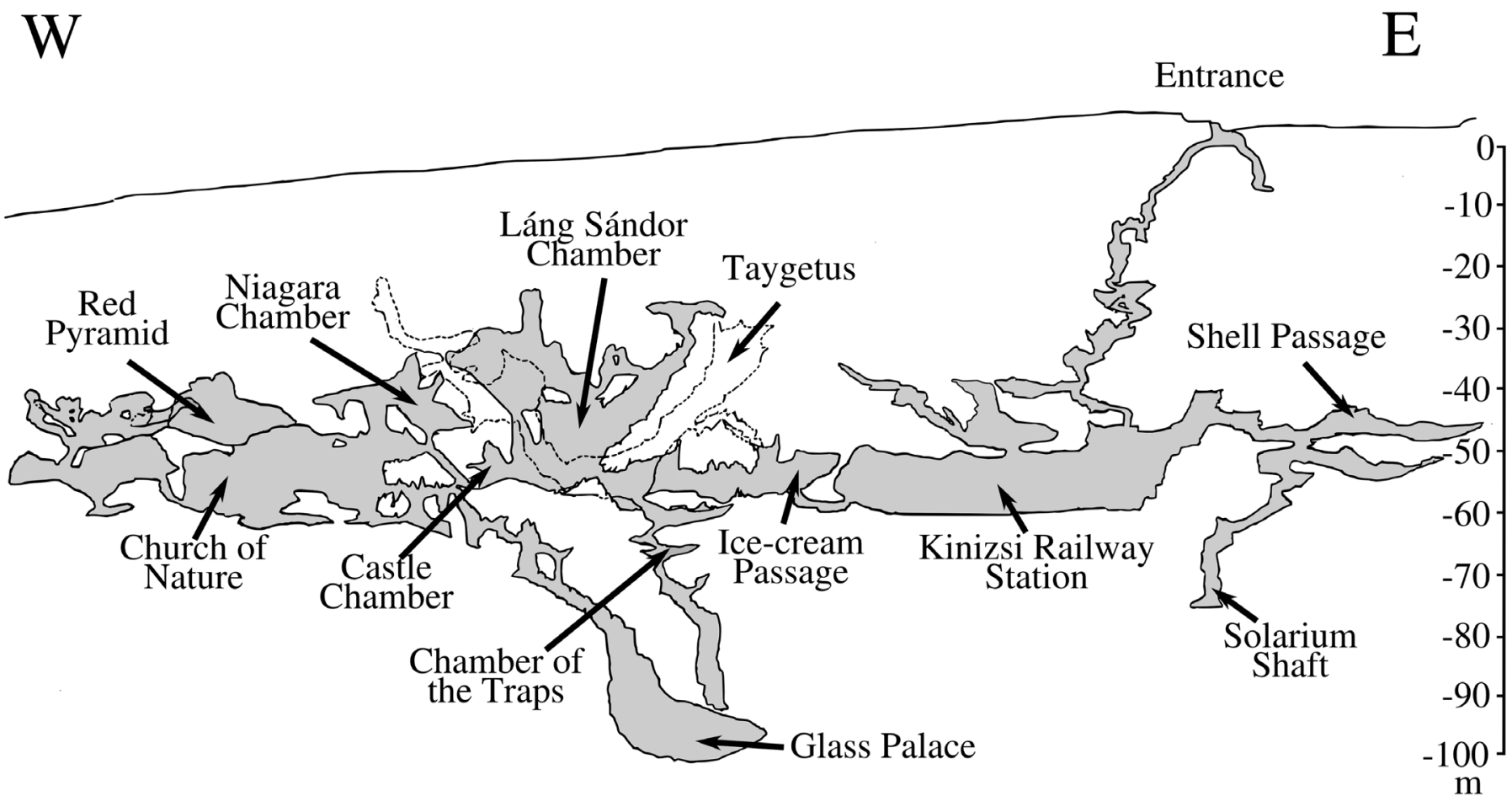

Fig. 4. Vertical section of the József-hegy Cave from the entrance $(218 \mathrm{~m}$ asl) to the deepest point of Glass Palace (115 $\mathrm{m}$ asl). Right axis shows the depth below entrance.

account. The upper limit of dating was $450 \mathrm{ka}$. The chemical process was accomplished at Eötvös Loránd University of Budapest, Hungary, in the laboratory of Gergely Surányi. The ICP-MS measurements were carried out in the Institute of Isotopes of the Hungarian Academy of Science. The detailed description of the chemical process can be found in Szanyi et al. (2009).

The vertical extent of the József-hegy Cave exceeds 100 m (Fig. 4). The authors collected samples in the József-hegy Cave for U-series dating in the whole passage-system, from the entrance $(218 \mathrm{~m}$ asl) to the deepest point (115 $\mathrm{m}$ asl). The most important ages derive from the analysis of cave rafts, because this calcite speleothem precipitates at or close to the karstwater table, thus it is a good indicator of paleo karstwater levels. However, the scarce appearance of cave rafts gave only limited information on the former water levels. We also examined multi-generation calcite coatings, and a few botryoid, gypsum and aragonite samples.

At first, in 1996 Leél-Össy analysed 38 samples in Bergen. Of them, 21 were younger than $350 \mathrm{ka}$, the upper limit of alpha spectrometric age determination. The samples and ages are listed in Table 1. In 2007, new samples were collected, and were analysed by Szanyi and Surányi. The collected samples and their ages are listed in Table 2.

\section{DESCRIPTION OF THE MINERALS AND SPELEOTHEMS}

A cave mineral is a homogeneous solid having a definite chemical composition and a 3-D ordered atomic arrangement, growing naturally within a cave (Self \& Hill, 2003). There are a few common mineral species in caves, yet there is a great variety in the speleothem forms that these minerals can take.
During specific cave development stages, the same mineral can form under different conditions taking different morphology. Here we present the minerals of the József-hegy Cave. The speleothems are classified according to their formation environment. A conceptual drawing was made to better explain the relationship between the speleothems and their formation environment (Fig. 5). After Hill \& Forti (1997), the authors define a speleothem subtype as a speleothem which has a structural identity similar to the type, but which has an origin different enough from the type so as to produce a deviant morphology with additional structural elements.

\section{Minerals predating the cave Barite}

Barite is always connected to tectonic fissures in the József-hegy Cave. It has undoubtedly precipitated from thermal waters and is much older than the cave. In the neighbouring Molnár János Cave and Ferenchegy Cave (Fig. 1), the barite often formed on top of calcite scalenohedrons. The scalenohedron crystals had intact surface planes, without any signs of redissolution. Thus it is reasonable to think, that the system was closed from the time of formation. The exact ages of them were not determinable, because they were older than the upper limit of the U-series disequilibrium dating method. However, the isotope content showed a non equilibrium state, which means that the sample is younger than $1 \mathrm{Ma}$. Thus, the barite is much younger than $1 \mathrm{Ma}$ so its direct connection with the Badenian or older volcanism is doubtful. Its formation may be linked to the post-volcanic activity what is supported by the low temperatures $\left(60-75^{\circ} \mathrm{C}\right)$ of solution from which barite precipitated (Dublyansky, 1995). 
Table 1. The results of the alpha spectrometric age determinations from the József-hegy Cave. The upper limit of age determination was 350 ka. The uncertainty is given at $\sigma$ level. The sample depth is measured from the entrance of the cave, which is at $218 \mathrm{~m}$ asl. The sample ages and altitudes above sea level are shown in Fig. 8.

\begin{tabular}{|c|c|c|c|c|c|}
\hline $\begin{array}{l}\text { Sample } \\
\text { number }\end{array}$ & Sample location & Description & $\begin{array}{c}\text { Age } \\
\text { (in ka) }\end{array}$ & $\begin{array}{l}\text { Uncertainty } \\
(+\sigma,-\sigma)\end{array}$ & $\begin{array}{l}\text { Depth below } \\
\text { entrance }(m)\end{array}$ \\
\hline $260196 / 13$ & $\begin{array}{l}\text { Deepest point of the } \\
\text { Glass Palace }\end{array}$ & Thin cave rafts & 66 & 4,4 & -103 \\
\hline $260196 / 3$ & $\begin{array}{l}\text { Kinizsi Railway Station, } \\
\text { under the Universe }\end{array}$ & $\begin{array}{l}\text { Upper part of the cave raft } \\
\text { sequence on the side wall }\end{array}$ & $>350$ & & -59 \\
\hline $240196 / 12$ & Castle Chamber & Fallen cave rafts on the floor & $>350$ & & -58 \\
\hline $240196 / 13$ & Castle Chamber & Bottom part of cave cone & $>350$ & & -56 \\
\hline $240196 / 13$ & Castle Chamber & Upper part of cave cone & 245 & 45,32 & -56 \\
\hline $260196 / 2$ & $\begin{array}{l}\text { Kinizsi Railway Station, } \\
\text { under the Universe }\end{array}$ & $\begin{array}{l}\text { Middle part of the cave raft } \\
\text { sequence on the side wall }\end{array}$ & $>350$ & & -57 \\
\hline $260196 / 1$ & $\begin{array}{l}\text { Kinizsi Railway Station, } \\
\text { under the Universe }\end{array}$ & $\begin{array}{l}\text { Bottom part of the cave raft } \\
\text { sequence on the side wall }\end{array}$ & $>350$ & & -56 \\
\hline $260196 / 4$ & Kinizsi Railway Station & Cave raft under the cave cones & $>350$ & & -56 \\
\hline $260196 / 15$ & Glass Palace & Thickened cave rafts & 86 & 4,4 & -98 \\
\hline $270196 / 1$ & Solarium Chamber & Homogeneous, thick flowstone & 106 & 3,3 & -50 \\
\hline $260196 / 14$ & Glass Palace & $\begin{array}{l}\text { Bottom of multi-generation } \\
\text { calcite coating }\end{array}$ & 108 & 7,6 & -95 \\
\hline $260196 / 14$ & Glass Palace & $\begin{array}{l}\text { Middle of multi-generation calcite } \\
\text { coating }\end{array}$ & 95 & 4,4 & -95 \\
\hline $260196 / 14$ & Glass Palace & $\begin{array}{l}\text { Top of multi-generation calcite } \\
\text { coating }\end{array}$ & 93 & 4,4 & -95 \\
\hline $260196 / 19$ & Castle Chamber & $\begin{array}{l}\text { Bottom of multi-generation } \\
\text { calcite coating }\end{array}$ & 278 & 175,68 & -54 \\
\hline $260196 / 19$ & Castle Chamber & $\begin{array}{l}\text { Top of multi-generation calcite } \\
\text { coating }\end{array}$ & 281 & 44,32 & -54 \\
\hline $260196 / 6$ & Chamber of Volcanoes & Corroded calcite coating & $>350$ & & -47 \\
\hline $260196 / 11$ & Kinizsi Railway Station & $\begin{array}{l}\text { Calcite coating lying on the floor, } \\
\text { pseudomorph }\end{array}$ & 206 & 10,10 & -60 \\
\hline $240196 / 4$ & $40 \mathrm{~m}$ from the Entrance & White calcite coating (botryoid) & $>350$ & & -23 \\
\hline $240196 / 17$ & $\begin{array}{l}\text { Entrance of the Castle } \\
\text { Chamber }\end{array}$ & $\begin{array}{l}\text { Thick calcite coating from the } \\
\text { side wall }\end{array}$ & $>350$ & & -57 \\
\hline $240196 / 3$ & $35 \mathrm{~m}$ from the Entrance & White calcite coating (botryoid) & $>350$ & & -17 \\
\hline $240196 / 2$ & $20 \mathrm{~m}$ from the Entrance & Thin calcite vein & $>350$ & & -11 \\
\hline $260196 / 5$ & Kinizsi Railway Station & $\begin{array}{l}\text { Calcite vein fallen from the } \\
\text { ceiling }\end{array}$ & $>350$ & & -51 \\
\hline $260196 / 9$ & Kinizsi Railway Station & $\begin{array}{l}\text { Calcite vein in the lower part of } \\
\text { the chamber }\end{array}$ & $>350$ & & -54 \\
\hline $270196 / 5$ & Storm Chamber & Calcite scalenohedrons & $>350$ & & -52 \\
\hline $260196 / 16$ & Bottom of Glass Palace & Glass-ball botryoid & 9 & $0.5,0.5$ & -90 \\
\hline $260196 / 12$ & Kessler Hubert Chamber & Glass-ball botryoid & 17.5 & $0.5,0.5$ & -53 \\
\hline $240196 / 5$ & Red-orange Chamber & Glass-ball botryoid & 61 & 30,24 & -39 \\
\hline $240196 / 8$ & Ice-cream Passage & Common botryoid on the floor & 117 & 3,3 & -56 \\
\hline $270196 / 4$ & Swan Neck & Common botryoid & $>350$ & & -46 \\
\hline $240196 / 16$ & Recess of Géza & botryoid & 248 & 17,15 & -54 \\
\hline
\end{tabular}




\begin{tabular}{|l|l|l|c|c|c|}
\hline $240196 / 6$ & $\begin{array}{l}\text { Entrance of Kinizsi } \\
\text { Railway Station }\end{array}$ & botryoid & $>350$ & -48 \\
\hline $240196 / 19$ & Castle Chamber & Dripstone botryoid & 150 & 8,7 & -58 \\
\hline $260196 / 18$ & Láng Sándor Chamber & $\begin{array}{l}\text { Slightly corroded aragonite } \\
\text { crystal }\end{array}$ & 158 & 8,7 & -53 \\
\hline $240196 / 14$ & El Dorado & Broken frostwork & 54 & 2,2 & -54 \\
\hline $260196 / 17$ & $\begin{array}{l}\text { Top of the shaft leading to } \\
\text { the Glass Palace }\end{array}$ & Frostwork & 32 & 1,1 & -70 \\
\hline $240196 / 15$ & $\begin{array}{l}\text { Middle of the Church of } \\
\text { Nature }\end{array}$ & Fallen frostwork & 92 & 6,6 & -61 \\
\hline $270196 / 3$ & Solarium Chamber & Fallen, thick gypsum crust & $>350$ & & -53 \\
\hline $240196 / 18$ & Castle Chamber & Fallen, large gypsum crystal & 61 & 10,10 & -51 \\
\hline
\end{tabular}

Table 2. The results of U-series age determinations using ICP-MS analysis. The uncertainty is given at $\sigma$ level. The sample depth is measured from the entrance of the cave, which is at $218 \mathrm{~m}$ asl.

\begin{tabular}{|l|l|l|c|c|c|}
\hline $\begin{array}{c}\text { Sample } \\
\text { number }\end{array}$ & \multicolumn{1}{|c|}{ Sample location } & \multicolumn{1}{|c|}{ Description } & $\begin{array}{c}\text { Age } \\
\text { (in ka) }\end{array}$ & $\begin{array}{c}\text { Uncertainty } \\
(+\boldsymbol{\sigma},-\boldsymbol{\sigma})\end{array}$ & $\begin{array}{c}\text { Depth below } \\
\text { entrance (m) }\end{array}$ \\
\hline J1 & Kinizsi Railway station & Cave raft from the side wall & 489 & 287,79 & -53 \\
\hline J3 & Chamber of the Traps & Cave raft & 107 & 3,2 & -93 \\
\hline J(SG-10) & Bottom of Glass Palace & Cave raft & 95 & 23,17 & -103 \\
\hline
\end{tabular}

In the József-hegy Cave, barite can be found in several places (e.g. in the Cholnoky Chamber or the Wave-Cut Notch Passage, Black Barite), without being widespread. The length of the edges of the barite tablets varies between 1 and $3 \mathrm{~cm}$ (Fig. 6a). The largest barite crystals can be found in the eastern end of the cave. These barite crystals are often covered by other precipitations, such as manganese coating (e.g. in the Cholnoky Chamber), limonitic coating (e.g. in the Solarium) and gypsum coating (e.g. in the Cholnoky Chamber). The most interesting one can be found in the Chamber of Volcanoes, where the dripstone coating precipitated on the barite debris. These fragments have broken from the ceiling veins and fell into bottom ponds. These ponds were rich in calcium carbonate, which precipitated as calcite crust and rounded the angular edges of the barite crystals (Adamkó \& Leél-Össy, 1986).

\section{Calcite}

Several types of calcite could precipitate from thermal water circulating in the cracks before the formation of the cave. When the precipitation filled totally the available space, vein calcite formed. Vein calcite occurs almost everywhere in the cave as a filling with massive texture microcrystals in cracks of a few millimetres to centimetres wide. If there was space in the crack, euhedral crystals grew too. Dublyansky (1995) determined fluid inclusion homogenisation temperatures of scalenohedral calcite as low as $55-90^{\circ} \mathrm{C}$. Besides normal scalenohedrons sometimes scalenohedron twins can be observed in paleokarst cavities (e.g. at the Swan Neck). These are large, $2-3 \mathrm{~cm}$, occasionally $5-6 \mathrm{~cm}$ long crystals (e.g. in the Fondue Chamber, Fig. 6b). At the Red Sea, pale yellow, translucent specimens occur. Dogtooth spar specimens of 1-3 cm length can be found in several places in the cave (e.g. in the Stone mine). In the Anaconda Chamber, stubby, $3 \mathrm{~cm}$ thick crystals are covered by a thin gypsum layer. Most frequently, it can be found in joints and fissures.

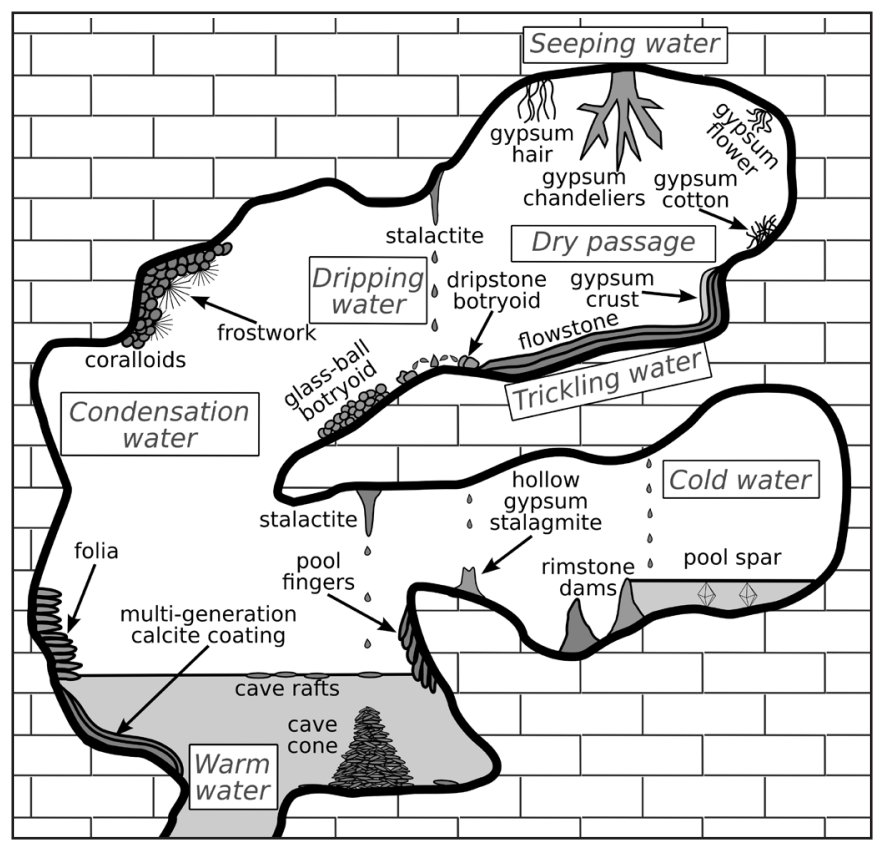

Fig. 5. Theoretical drawing of formation environments and associated speleothems in the József-hegy Cave (not to scale). 


\section{Speleothems formed under warm water Calcite}

At the surface of the motionless water pools, which are rich in calcium bicarbonate, calcite precipitates as a calcite film, forming the cave raft. If the weight of the rafts exceed the capacity of surface tension to support them or a surface disturbance occurs then they drift to the pool bottom. There the cave rafts become overgrown by calcite and form raft origin sunken objects (roso). These thickened rosos occur in the Kinizsi Railway Station, the Castle Chamber, the Glass Palace, and the Shell Branch. For the research on cave development, this kind of speleothem provided the most important radiometric dating results. The thicknesses of rosos in the József-hegy Cave are normally in centimetre scale, what supports the warm water origin. In the Glass Palace, even the thickest pieces are transparent and translucent and generally have a pinkish shade of colour. At some places, cave raft forms also at the surface of cold water basins, for example at the bottom of the Glass Palace. A special accumulation of them is the cave cone, resembling a snow-bound pine. In this case, the cave rafts break always at the same spot due to regularly dripping. After sinking to the bottom of cave lake, they pile-up there and become overgrown by calcite forming surprisingly sharp, column-like cones (Fig. 5). This item is called "Christmas tree" in Hungary. In the Castle Chamber and the Kinizsi Railway Station, their height may even exceed $2 \mathrm{~m}$. These forms were misinterpreted by Panoš (1960) as geyser-stalagmites (geysermites).

Folia are about half $\mathrm{cm}$ thick and a few centimetres deep wavy ribs on the side wall. They form at the level of fluctuating water table, and as such mark the positions where water table persisted for relatively long time. In the József-hegy Cave, this speleothem was found in the Blood Creek Chamber and Castle Chamber. Pool fingers (also referred to as "subaqueous stalactoids") are stalactite-shaped speleothems formed subaqueously in cave pools. Their formation mechanism is still unknown, though they are thought to be of biogenic origin (Melim et al., 2008). They have a tubular structure and rounded edges, and their thickness is 1-2 cm. In the Józsefhegy Cave, pool fingers grew parallel to the walls, forming a vertical succession (Fig. 5). They can be seen in mass on the northern side wall of the Kinizsi Railway Station and the Castle Chamber. Folia and pool fingers were precipitated from the warm water and indicate its level.

Multi-generation calcite coating is usually built up of 2-4 layers. As it can be seen in Fig. 7a during the formation of this coating, between its layers some cave raft samples were incorporated. This means, that their formation took place at the same time, from the same environment, thus this multigeneration calcite coating is of warm water origin. This is also proven by the ages of the coating. In the József-hegy Cave, it is 1-5 cm thick, however it can reach $20 \mathrm{~cm}$ as seen at the Black Barite. Its surface is rough, uneven, and rounded. It blunts and rounds the edges and corners of the walls and fallen rocks (Fig. 7). At some places, it may be found also on the floor. The most frequent occurrence of this form can be found in the passages of the Airport, where it is the predominant speleothem. Gypsum crystals precipitated on them. In the Kinizsi Railway Station and the Ice-cream Passages, this calcite coating even preserved the shape of the desiccated and cracked clay as a millimetre-thin coating.

\section{Minerals of manganese}

In the Chamber of Mourning, BM Passage and the Eastern Labyrinth, a black manganese coating of a few tenth of a millimetre covers the surface of the rock. At the Black Barite and in the Cholnoky Chamber, this black coating can be observed also on the surface
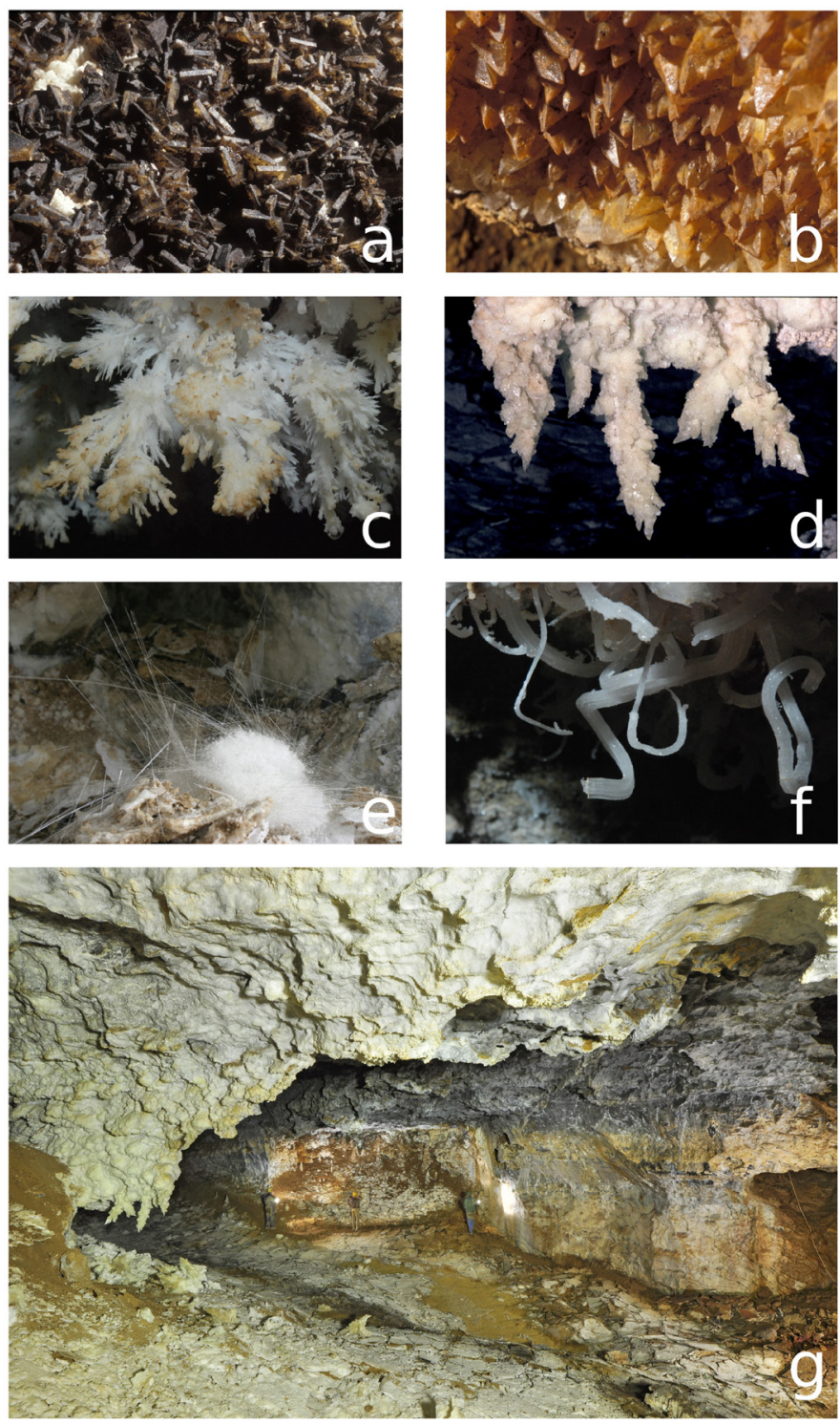

Fig. 6. Photographs of some speleothems from the József-hegy Cave. a) Barite crystals at Black Barite (photo by Csaba Egri), every tablet has an edge of $1-2 \mathrm{~cm}$. b) Calcite scalenohedrons in the Stone mine (photo by Csaba Egri), the photo shows an approximately $8 \times 6 \mathrm{~cm}$ part of the occurrence. c) Frostwork in the Church of Nature, approximately $10 \times 6 \mathrm{~cm}$. d) Gypsum chandeliers in the Kinizsi Railway Station, approximately $2 \times 1.5 \mathrm{~m}$. e) Gypsum cotton in the Shell Passage, the photo shows an approximately $50 \times 25 \mathrm{~cm}$ area. f) Gypsum flowers in the Red Sea Chamber, $15 \times 10 \mathrm{~cm} . \mathrm{g}$ ) View of the Kinizsi Railway Station, the biggest hall of the József-hegy Cave. The photo shows an approximately $30 \mathrm{~m}$ wide and $20 \mathrm{~m}$ high area. 


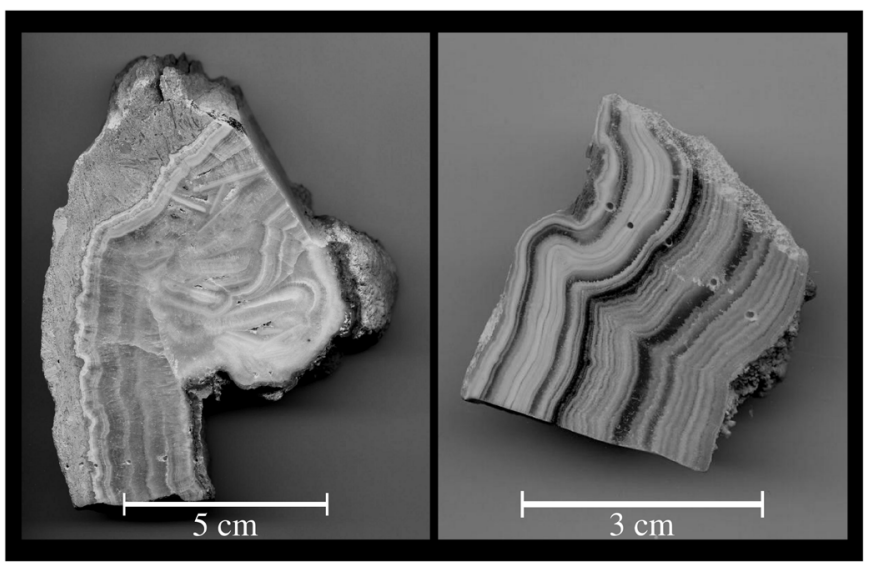

Fig. 7. Multi-generation calcite coating samples used for age determinations. Sample 260196/26 (Castle Chamber, left), and sample 210196/14 (Glass Palace, right). Thin layers are clearly visible in both samples. This coating of warm water origin rounds the edges of the walls. Determined ages are listed in Table 1.

of barite and gypsum crystals. This coating consists of hollandite and romanechite (Nagy, 2008). In the authors' opinion, the Mn content of the manganese coating is a product of bacteria. Probably, it is not or not only of recent origin, since in several places it does not cover the botryoid precipitations, but only the calcite crust at their base.

\section{Speleothems from solutions condensed from vapour above warm water pools}

By this origin we mean that the warm water lakes situated in the deeper levels of the cave evaporate and their mist condenses on the cold rock surface. As this aggressive water migrates, it takes up minerals in solution. At a later stage, precipitation takes place from this thin water film.

\section{Calcite}

Coralloid is a term describing a variety of nodular, globular, botryoidal or coral-like speleothems. Most coralloids are subaerial deposits generated by capillary film water, while others are of subaqueous origin. Several types of coralloids can be found in the József-hegy Cave, and none of them is considered as of subaqueous origin. This is supported by the ages of the coralloids, which are always higher, than the water level marker cave rafts or multi-generation calcite coating at the same time. A good example for this is the 117 thousand years old common botryoid sample at $162 \mathrm{~m}$ asl (sample no. 240196/8 in Table 1 ), and the water level-marker cave raft of $107 \mathrm{ka}$ at $123 \mathrm{~m}$ asl (sample J3 in Table 2). This suggests, that the water level has already dropped by the time of formation of these coralloids and the vapour originated from nearby thermal pools. The formation of vapour originated coralloid has stopped. The youngest sample is $117 \mathrm{ka}$ old.

Popcorn is an agglomeration of spheroidal forms, usually a bit smaller than a green pea. In the Józsefhegy Cave, its white crystals cover the wall with an extreme thickness in many places (e.g. in the Icecream Passage, the Láng Sándor Chamber, the Kadić Branch). Usually it spreads over the walls, but it can be locally found even on the floor (e.g. in the Pathfinder
Passage, the Airport, the Ice-cream Passage). The powder diffraction examinations did not detect the presence of aragonite, not even in traces. Thus, it is likely that they precipitated from solution directly as calcite. In the thin sections (Nádor, 1992; Leél-Őssy \& Surányi, 2003) it was observed that the precipitation was not continuous and steady, as re-dissolution surfaces can also be frequently found between the layers of various thickness

Common botryoid (coralloid in Hill \& Forti, 1997) is the most frequent botryoid variety in the Józsefhegy Cave. They often cover the whole wall and appear as $5-15 \mathrm{~cm}$ long, ramifying, sheaf-like clusters that stand out perpendicularly from the side walls (e.g. in the Ice-cream Passage). In the Kinizsi Railway Station, the Kessler Hubert Chamber and at the El Dorado, even re-dissolved speleothems can be observed. In the József-hegy Cave this is called common botryoid due to its frequent occurrence.

Angular botryoids are bounded by rhombus faces with an edge length of less than $0.5 \mathrm{~cm}$, so they do not have the usual irregular spherical shape. They were mentioned by Takácsné Bolner (1989) in the Pál-völgy Cave. In the József-hegy Cave, this rhombohedral form can be observed in the Chamber of Volcanoes and on the Balcony above the Church of Nature.

\section{Aragonite}

Deposition of frostwork is from subaerial capillary films supplied by dripping water or from vapour. In the Kessler Hubert Chamber, the El Dorado, the Church of Nature and the Kadic Branch, 1-2 mm thin aragonite crystalline needles (Fig. 6c), bounded by plain faces, form hedgehog-like hemispheres of 1-3 $\mathrm{cm}$ in diameter. They are built-up of needles of equal size, slightly thinning out towards their ends. The $4-8 \mathrm{~cm}$ long clusters of these hemispheres resemble a pine with their multiple ramifications. However, 1 $\mathrm{cm}$ long needles as thin as hair can also be found. At some places, sceptre-like overgrowth can also be observed. Often the crystalline needles are covered by calcite (e.g. in the Kessler Hubert Chamber and the El Dorado). In general, they hang down from the ceiling like in the El Dorado, but sometimes stand out perpendicularly from the vertical side wall (e.g. at the entrance of the Red Sea).

Aragonite is easily re-dissolved in the infiltrating waters. We observed the re-dissolution process in the Kessler Hubert Chamber, the El Dorado, the Kinizsi Railway Station and the Chamber of Volcanoes. At this time, this leads to a visible change at the tips of the crystalline needles heading towards the floor, as the water-drops grow slowly until they reach a critical mass. After dropping down, growth of the next waterdrop begins immediately and, as long as the surface tension overcomes the force of gravity, the needle tips permanently stand in water and dissolve continuously. When dropping down, part of the calcium carbonate content, dissolved in the water-drop, is precipitated at the tip of the aragonite needle as calcite. Sometimes, the re-dissolution affects also the botryoids, which host the frostwork, thus their surfaces become rough due to the uneven dissolution.

Based on their morphology and radiometric dating, the frostwork was formed after the regression of the 
water. While the water level was at $120 \mathrm{~m}$ asl - as indicated by the 86 ka cave raft (sample 260196/15 in Table 1) - frostwork formation took place at $157 \mathrm{~m}$ asl (sample 240196/15 in Table 1). Considering the ages, it may be assumed that - as in the case of the common botryoid - frostwork precipitation was connected to the evaporating of warm water from lakes, situated deeper than the place of frostwork formation. In case of the youngest frostwork samples, the water level could be below the level of the known cave.

\section{Dolomite}

Dolomite was first found in the samples collected in 1985 (Kleb et al., 1993). At that time, however it was still not clear whether the dolomite was originating from the surrounding rocks or from the ascending water. In 1992, above the Gypsum Cemetery, crystalline needles, seeming to be aragonite, were collected. About half of them proved to be composed of dolomite according to the X-ray powder diffraction examinations by Kleb et al. (1993). Dolomite is also present in some cave raft samples. Altogether, dolomite was detected in 9 samples, its ratio being of 6-58 mass \%.

\section{Cold water speleothems}

\section{Calcite}

Around the Red Pyramid, the precipitating carbonate formed barely $1-2 \mathrm{~cm}$ tiny rimstone dams due to $\mathrm{CO}_{2}$ escaping from the slowly flowing cold water. Behind them, water is accumulating in small ponds. From this cold water, pool spar, several millimetres in size are precipitating (Fig. 5).

\section{Speleothems in dry passages}

We call a cave passage dry, if it was air-filled and had no direct connection with warm water during the time when the below-mentioned speleothems were deposited. This includes places where dripping, seeping, or trickling flowing water was present.

\section{Gypsum}

Gypsum chandeliers are stalactites with splaying arms, which resemble glass chandeliers (Fig. 6d). The biggest ones are $50-80 \mathrm{~cm}$ long in the Gypsum Cemetery, Kinizsi Railway station and Castle Chamber - similar, but smaller than in Lechuguilla Cave (Hill, 1987). They have always been precipitating on the ceiling, but the heaviest specimens have fallen and now lie on the floor. They are thicker at their stems, and then ramify into 3-4 directions like widely opened fingers (Fig. 5). Chandeliers form in areas of weak dripping where gravitational flow turns into capillary-controlled flow (Hill \& Forti, 1997).

Gypsum crust consists of $1-2 \mathrm{~mm}$ crystals, resembling granular snow, and covers whole walls in several places (e.g. in the Kinizsi Railway Station as seen in Fig. 6g, Ice-cream Passage, etc.). Due to its softness and its low adherence to the walls, this form is extremely susceptible to damage: accidental touch of speleologists' muddy clothes irrecoverably and uncleanably contaminates the crystal grains. The impurities transported by the percolating water are deposited on the horizontal and oblique surfaces and embedded into the crystal lattice as inclusions. Thus, upward facing surfaces were coloured already at the time of their discovery, whereas the crusts of the vertical and curved surfaces have mostly remained snow-white. The thickness of the crust is generally a few centimetres and on its surfaces 1-2 cm long, barely 1-3 mm wide crystalline needles can often be seen (e.g. in the Ice-cream Passage and in the Church of Nature).

The gypsum crust originates from the oxidation of pyrite disseminated in marl horizon that overlies the limestone. The sulphate-rich solutions infiltrated into the cave along bedrock's network of fissures. The water has partly dissolved the gypsum content of marls, and the sulphate-rich solutions were re-precipitated on the walls of the cave as gypsum crusts, from which large crystals sometimes individualise (Palmer, 2007). These large crystals can form groups (e.g. in the Solarium), consisting of $1-5 \mathrm{~cm}$ long, usually twinned crystals with corroded, re-dissolved surfaces. Between them the original crust of tiny crystals is still present.

Gypsum also exists as precipitation on other crystals. The dried up clay tablets on the floor of the Kinizsi Railway Station (Fig. 6g) and the Ice-cream Passage are covered by a thin calcite coating. In many occasions, the clay is gone but this coating has preserved the original shape of clay tablets. Upon this calcite coating, a thin, microcrystalline, glossy gypsum coating is present which could probably grow by capillary-film mechanism or by chemical alteration of calcite by acidic gases such as $\mathrm{SO}_{2}$. Gypsum frequently occurs on the tip of the frostwork, and it may cover dripstone (Church of Nature, Castle Chamber) and barite crystals (Cholnoky Chamber) as well.

Fibrous speleothems are those that display a crystal habit that is fibrous or filamentary. They can be divided into 4 subtypes, depending on the length of the crystal fibres and the way in which the fibres intertwine with each other. The lonely crystals, which are single fibres, form the gypsum hair or thread. Bunches of single fibres form the cave cotton. The fibres that are matted together compose rope and the fibres, which split make up flowers (Hill \& Forti, 1997).

Gypsum hair up to $90 \mathrm{~cm}$ long has been reported from three sites in the József-hegy Cave (e.g. in the Crystalline Chamber of the Shell Branch), although the length of the fibres is generally between 10 and 30 $\mathrm{cm}$. Among the millimetre thin crystal fibres, we have found (under binocular microscope) even a swallowtailed twin crystal. The gypsum content of the fibres was also confirmed by X-ray powder diffraction examinations (Leél-Őssy \& Surányi, 2003).

Cave cotton is a subtype of fibrous speleothem composed of masses of intergrown, fibrous or needlelike crystals. This speleothem appears only in the Shell Branch and in the Glass Palace (Fig. 6e). Cave cotton usually forms on floor sediment or bedrock ledges, but it can also form on cave ceilings. In the József-hegy Cave most of them hang down from the ceiling or the walls so they look like beards and whiskers. Gypsum beards 40 to $50 \mathrm{~cm}$ long occur in the József-hegy Cave. They are extremely sensitive and susceptible to damage, they sway even at normal speech sound. 
Gypsum flowers form in relatively dry, not dripping conditions (Fig. 5). They result from local feeding of solutions through pores in the rock, under capillary pressure. In the case of gypsum, the solution is calcium sulphate. Due to a deformation along translational planes, the growing crystals are frequently bent, spirally twisted and form gypsum flowers, sometimes with a length of $10-15 \mathrm{~cm}$. Opening like flowers, the crystals with a fibrous appearance and a diameter of 1-2 $\mathrm{cm}$ (anthodites, according to the terminology of Ghergari \& Onac, 1995) grow generally upwards (e.g. in a niche of the Castle Chamber), while the smaller crystals of maximum 4-5 millimetres (oulophites, according to the terminology of Ghergari \& Onac, 1995), which have not only a bent $C$ axis but also fibres twisted several times around their longitudinal axis, grow generally downwards. The most beautiful examples can be seen in the Anaconda Chamber, in the Flower Garden and in the Red Sea (Fig. 6f). The gypsum flowers are growing at this moment too (Ghergari \& Onac, 1995).

Cave blisters are hemispherical, bulged deposits filled with clay, sand or a diverse variety of mineral substances. Blisters are usually found attached to coatings and crusts, coralloids, flowstone, dripstone, or cave walls. They have feeder holes in their backs where they are attached to the walls. (Hill \& Forti, 1997). The blisters in the front of the Universe Chamber are of a few centimetres in diameters and have $2-3 \mathrm{~mm}$ thick walls and they are attached to the gypsum crust.

Hollow gypsum stalagmites can be found in the Butterfly Chimney, the Castle Chamber, and the El Dorado. The thickness of their walls varies on the millimetre-centimetre scale, while their diameter varies between 1 and $20 \mathrm{~cm}$, which depends on the distance between the ceiling and the floor, that is the energy of dripping. Their height may reach 30-40 $\mathrm{cm}$. Klimchouk et al. (1995) mentioned similar but essentially larger pieces in Ukraine as cylindrical rims.

\section{Calcite}

The glass-ball botryoid is a regularly spheroidal, reddish-brown, or yellow speleothem of about 0.5 $\mathrm{cm}$ diameter with a smooth surface. This subaerial coralloid forms in dry passages by thin films of water flowing over wall irregularities. This speleothem was described from the Glass Palace, the Kessler Hubert Chamber and the Kinizsi Railway Station (Leél-Össy \& Surányi, 2003).

Draught botryoid precipitates from the streaming air. In the József-hegy Cave, the most beautiful specimens can be found in front of the entrance of the Airport. They have a diameter of maximum 1-3 $\mathrm{mm}$. The snow-white small lime knots are supported by a tiny, thin stem and frequently have sphere-like shapes (Cser \& Gádoros, 1988).

In the Chamber of Volcanoes and at the bottom of the Castle Chamber, a relatively large, $1-3 \mathrm{~cm}$ botryoid type with irregular shape, the dripstone botryoid (local name) can be seen. Its name refers to the condition that it is forming under the dripping water (Fig. 5).
Calcite dripstones are of secondary importance in the József-hegy Cave despite the active dripping at several places. There are extremely beautiful specimens of different colours that can be assigned into two groups: clear, transparent, translucent dripstones, and totally opaque precipitations. The specimens of the first can be mainly found in the Church of Nature and the Glass Palace, dissolved in Triassic limestone, while those of the latter can be rather observed in passages lying in the more clayey Eocene limestone (e.g. in the Blood Creek Chamber). The Chamber of Volcanoes is characterised by small, pale yellow stalactites. In the Chamber of the Red Pyramid, there is a stalagmite that resembles an Aztec pyramid.

Flowstone is rare in the József-hegy Cave. It forms where thin films of water flow over large surface area, $\mathrm{CO}_{2}$ is lost and carbonate material is precipitated, resulting in thin layers. These layers are orange in the Church of Nature and blood-red in the Blood Creak Chamber.

\section{Hydromagnesite and huntite}

Snow-white, soft speleothem samples were collected in the entrance section. The X-ray powder diffraction analyses of this form showed a hydromagnesitic composition. This was the first proved hydromagnesite occurrence in Hungarian caves. In some samples within the entrance section of the cave, the existence of huntite was proved as well (Kleb et al., 1993).

\section{Speleothems derived from alteration of the bedrock Clay minerals (kaolinite, montmorillonite)}

Due to the weathering of the marl layers above the cave, a large amount of clay gets into the passages besides the dissolution residue. In general, the clayey fillings have a thickness of 1 metre, but locally (in the case of the Sahara) the filling may reach 3-4 $\mathrm{m}$. According to the X-ray examinations as well as the DTA analyses (Kleb et al., 1993), their mineral composition is made up of kaolinite and montmorillonite. These minerals are residual deposits of Eocene limestone and marl.

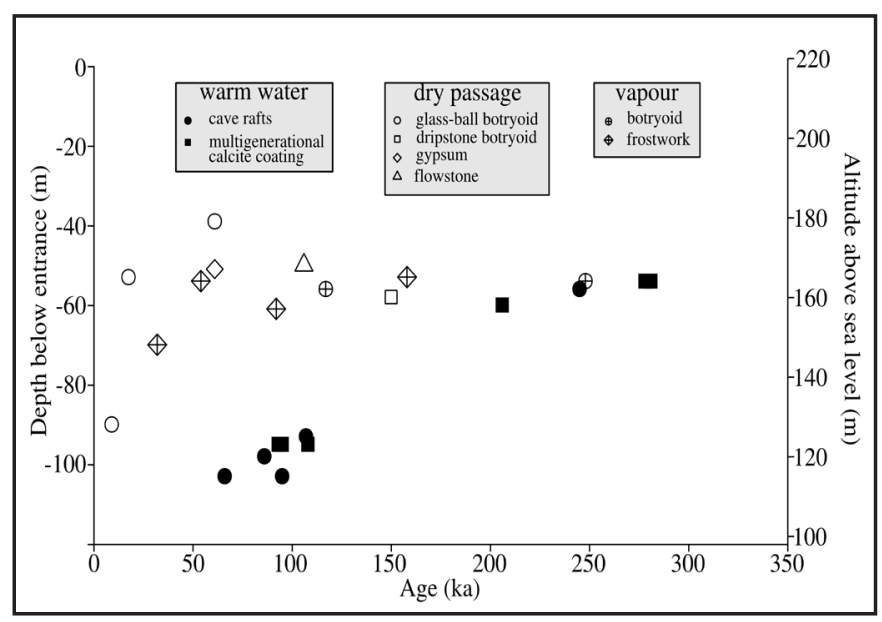

Fig. 8. The determined ages of speleothems from the József-hegy Cave with corresponding depth below entrance on the left and altitudes above sea level on the right. 


\section{Goethite}

At the bottom of the passages in the Szépvölgy Limestone and the Buda Marl, clayey detritus has a typical brownish-reddish colour caused by its goethite content. In the side walls of passages, which are dissolved in marls at higher levels (e.g. the BM Passage), 3-10 cm lenticular-spheroidal goethite nodules can be seen, which are probably transformed from pyrite. In the Fondue Chamber a goethite stalactite about $10 \mathrm{~cm}$ long that precipitated from dripping water oozing through a goethite nodule was found. In the vicinity of the Solarium Chamber, goethite coating gives the barite crystals a reddishbrownish as well as pink colour.

Kleb et al. (1993) carried out X-ray powder diffraction and derivatograph examinations on some minerals of the József-hegy Cave. Analysing the clayey filling, he detected quartz in the sample. In 1997, an X-ray photograph by György Lovass on a goethite nodule also showed a certain quartz content (Kleb et al., 1993).

Studying the heavy mineral content of the filling of the BM Passage, Kleb et al. (1993) identified relatively much yellow, transparent garnet with vitreous lustre as well as a few zircon and un-determinable bottlegreen pyroxene grains, besides geothite.

\section{DISCUSSION}

With the discovery of the József-hegy Cave, a cave of hydrothermal origin with an abundance of minerals unknown so far in Hungary came to light. Diversity and the frequency of the occurrence of crystals make this cave similar to the Lechuguilla Cave, the precious treasure of Carlsbad Cave National Park, Guadalupe Mountains, New Mexico, USA, which is considered the most beautiful cave in the world - even if the dimensions of the mineral precipitations and the passages do not compare in scale.

The reasons for the relative poverty in dripstones are the composition of the dripping waters and, ultimately, the overlying marl, which is relatively poor in calcium carbonate. According to the measurements of Kleb et al. (1993), the $\mathrm{HCO}_{3}$ - content of dripping waters is so low in the caves of Rózsadomb that they cannot be regarded as karstwaters. The $\mathrm{HCO}_{3}$ content of the water sample from the dripstone section of the József-hegy Cave (passages above the Glass Palace) is more than twice as much as that of the dripping water from the dripstone-free section of the cave, but even so it is only $177 \mathrm{mg} / 1$. At the same time, the sulphate content of this water is $200 \mathrm{mg} / 1$. This explains the richness of the cave in gypsum precipitations.

If we consider the formation environments of the speleothems (Fig. 5), we can define the paleo water levels and draw some hypotheses on the age of the cave. Based on the age determination, it was possible to reconstruct the change in the paleo water level, which served as a base of comparison for the age of the other precipitations that are older than the cave or formed after the final recession of water. The determined ages versus height above sea level or depth below entrance are shown in Fig. 8 .

One of the most important water level marker speleothems is the cave raft, because it precipitates close to the water surface. Some of the dated cave rafts were older than the upper limit of alpha spectrometric age determinations, thus the passage level at approximately $160 \mathrm{~m}$ above see level was already air-filled $350 \mathrm{ka}$ ago. The water level was still around $160 \mathrm{~m} 250 \mathrm{ka}$ before present, which is shown by the relatively young cave cone at the Castle Chamber (Sample no. 240196/13 in Table 1). The cave rafts at $115-120 \mathrm{~m}$ asl are the youngest dated in the cave (sample no. 260196/13, 260196/15 in Table $1)$. The karstwater surface subsided to this level by the time of 86-66 ka before present.

The forming of multi-generation calcite coating is also connected to warm water. The dating of the distinct layers revealed that the forming of the coating lasts for $10-20 \mathrm{ka}$ at maximum. The ages are in good agreement with the ones for the cave rafts. The samples at $164 \mathrm{~m}$ asl are $280 \mathrm{ka}$ old (260196/19 - two layers), which confirms the place of the karstwater level derived from the cave raft sample. The ages of the deepest multi-generation calcite coating are a proof of the water level being at $120 \mathrm{~m}$ approximately 100 ka ago.

At the Kinizsi Railway Station the calcite coating covers the desiccated clay tablets. This might have precipitated from the water during repeated but shorter floods following the temporary regression of water. This coating (sample no. 260196/11) is 206 ka old, only a little younger than the other samples of the same altitude, thus the connected water level fluctuation must have been only a minor alteration of the order of a few metres.

Flowstones precipitate in air-filled passages from trickling waterfilms. The kartswater level in the Józsefhegy Cave subsided to $120 \mathrm{~m}$ asl approximately 110 ka ago, thus the $106 \mathrm{ka}$ old flowstone at $168 \mathrm{~m}$ asl could form in the air-filled passage.

All of the gypsum speleothems were formed under subaerial conditions. This is consistent with their ages and the above estimated water level.

All the samples that were taken near the surface (e.g. sample 240196/4, 240196/3) are older than the upper limit of the alpha spectrometric age determination. These old speleothems, formed under subaerial conditions, suggest that the water left the passages more than $350 \mathrm{ka}$ ago, which is also confirmed by the old cave raft samples around 158 $\mathrm{m}$ asl.

\section{CONCLUSIONS}

On the basis of our investigation, the minerals and speleothems of the József-hegy Cave can be classified into groups. First, there are speleothems, which are older than the cave: barite, calcite vein, calcite scalenohedron and dogtooth spar. In the second group are the speleothems which precipitated from warm water, such as cave raft, folia, pool fingers, multi-generation calcite coating and manganese coating. The third group consists of those speleothems which precipitated from solutions derived from the vapour of warm lake: popcorn, common botryoid, angular botryoid, frostwork and dolomite crystals. Cold water speleothems, like rimstone dams and pool spar form the fourth group. The speleothems of the 
fifth group are independent from the warm water, and subsequently developed in the dry passages: gypsum chandeliers, crust, hair, cotton, flower, cave blisters, hollow gypsum stalagmite, calcite glass-ball botryoids, drought botryoid, dripstone botryoid, dripstone and flowstone. To this group belong the hypdromagnesite and huntite minerals. Some minerals are derived from the alteration of the bedrock. These are the clay minerals (kaolinite, montmorillonite) and geothite. Resedimented minerals are quartz, garnet, zircon and pyroxene.

The upper limit of age determination restrains our conclusions. On the base of 41 measurements, we know that speleothems started to develop in the upper level of the cave more than $350 \mathrm{ka}$ ago. Some of these dated old speleothems were developing in dry passages, thus, we can conclude, that the uppermost passages of the József-hegy Cave have been dry at least for $350 \mathrm{ka}$. The karstwater level was still at the main passage $200 \mathrm{ka}$ ago, however the calcite crust covering the desiccated clay tablets shows a smaller water level fluctuation. The water level subsided to $120 \mathrm{~m}$ asl by the time of $100 \mathrm{ka}$ before present. The water subsidence was accompanied by the formation of speleothems by vapour condensation. The growth of speleothems in the dry passages started as well.

\section{ACKNOWLEDGEMENTS}

We are very grateful to Prof. Stein-Erik Lauritzen for giving us the opportunity to use his U/Th dating laboratory in Bergen and for his guiding during the work; Silviu Constantin is thanked for his advice to compile this material. Zsolt Varga helped detecting radioactive content during our U-series measurements in Budapest. Csaba Egri supplied photographic material and Gábor Gercsák helped improving the English text of this paper. Suggestions by two anonymous reviewers and Bogdan P. Onac helped to improve the manuscript. We acknowledge the Ministry of Rural Development for granting permission to perform our research.

\section{REFERENCES}

Adamkó P. \& Leél-Őssy Sz., 1986 - Budapest új csodája: a József-hegyi-barlang. (New wonder of Budapest: the József-hegy Cave). Karszt és Barlang, 1984: 1-8.

Adamkó P., Dénes Gy. \& Leél-Őssy Sz., 1992 - Caves of Buda. Issue of the Council of Budapest, $47 \mathrm{p}$.

Bakalowicz M.J., Ford D.C., Miller T.E. \& Palmer A.N., 1987 - Thermal genesis of solution caves in the Black Hills, South Dakota. Bulletin of the Geological Society of America, 99: 729-738.

Báldi T., 1986 - Mid-tertiary stratigraphy and paleographic evolution of Hungary. Akadémiai Kiadó, Budapest, 201 p.

Cser F. \& Gádoros M., 1988 - The role of aerosols in cave depositions. Košice: Proceedings of the International Symposium, on Phys., Chem., Hydrogeol. Karst: 25-34.

Dublyansky Y.V., 1995 - Speleogenetic history of the Hungarian hydrothermal karst. Environmental Geology, 25: 24-35.
Dublyansky Y.V., 2000 - Hydrothermal Speleogenesis in the Hungarian Karst. In: Klimchouk A.B., Ford D.C., Palmer A.N. \& Dreybrodt W. (Eds.): Speleogenesis. Huntsville, Alabama, National Speleological Society, 298-303.

Fodor L., Leél-Össy Sz. \& Tari G., 1991 - En-echelon fractures in a dextral shear zone-Tectonic heritage for a hydrothermal cave (Budapest, Hungary). Terra Nova, 4: 165-170.

Fodor L., Magyari Á., Fogarasi A. \& Palotás K., 1994 - Tercier szerkezetfejlődés és késő paleogén üledékképződés a Budai-hegységben (Tertiary tectonics and Late Palaeogene sedimentation in the Buda Hills, Hungary. A new interpretation of the Buda Line). Földtani Közlöny, 124(2): 129-305.

Ford D.C. \& Takácsné Bolner K., 1992 - Abszolút kormeghatározás és stabil izotóp vizsgálatok budai barlangi kalcitmintákon (Absolute age determination and stable isotope measurements on calcite samples from Buda Hills). Karszt és Barlang, 1991: 11-18.

Ford T.D., 1995 - Some thoughts on hydrothermal caves. Cave and Karst Science, 22(3): 107-118.

Gatter I., 1984-A karbonátos kőzetekérkitöltéseinekés a barlangok hévizes kiválásainak folyadékzárvány vizsgálata (The fluid inclusion measurement of veins of calcareous rocks and the hydrothermal precipitations of the caves). Karszt és Barlang, 1984(1): 9-18.

Ghergari L. \& Onac B.P., 1995 - The crystallogenesis of gypsum flowers. Cave and Karst Science 22: 119-122.

Haas J. (Ed.), 1993 - Magyarország litosztratigráfiai alapegységei (Basic lithostratigraphic units of Hungary). MÁFI, Budapest, 278 p.

Hill C.A., 1987 - Geology of Carlsbad Cavern and other caves in the Guadalupe Mountains. New Mexico Bureau of Mines and Mineral Resources Memoires, 117, 150 p.

Hill C.A. \& Forti P., 1997 - Cave Minerals of the world ( $2^{\text {nd }}$ ed.). National Speleol. Soc., Huntsville, USA, $463 \mathrm{p}$.

Horusitzky H., 1939 - Budapest jobb parti részének hidrogeológiája (Hydrogeology of the right side bank part of Budapest). Hidrológiai Közlöny, 18: 1-404.

Jakucs L., 1948 - A hévforrásos barlangkeletkezés földtani és fizikai tényezöi (Geological and physical factors of hydrothermal cave genesis). Hidrológiai Közlöny, 28: 53-58.

Jakucs L., 1994 - A Budai-hegység hidrotermális karsztja (The hydrothermal karst of the Buda Hills). Földrajzi Értesítö, 43(3-4): 235-246.

Jaskó S., 1936 - A Pálvölgyi-rózsadombi barlangvidék (The Pálvölgy-Rózsadomb cave region). Természettudományi Közlöny, 68: 224-225.

Kessler H., 1957 - Az örök éjszaka világában. (In the realm of everlasting night). Budapest, Kossuth, $179 \mathrm{p}$.

Kleb B., Sárváry I., Maucha L., Korpás L., Török Á. \& Benkovics L., 1993 - Közettani, tagoltsági, kőzetfizikai vizsgálatok, földtani reambuláció és paleokarszt elemzés. (Geological, petrophysical, tectonic and palaeokarst analyses and evaluation). Manuscript, Technical University of Budapest, 700 p. 
Klimchouk A.B., Nasedkin V.M. \& Cunningham K.I., 1995 - Speleothems of aerosol origin. Bulletin of National Speleological Society, 57: 31-42.

Kovács J. \& Müller P., 1980 - A Budai hegyek hévizes tevékenységének kialakulása és nyomai. (Evolution and traces of thermal water activity in the Buda Mts.) Karszt és Barlang, 1980(2): 93-98.

Kozur H. \& Mock R., 1991 - New Middle Carnian and Rhaetian conodonts from Hungary and the Alps. Jahrbuch Geol. Bundesans, 134(2): 271-297.

Kraus S., 1991 - A budai barlangok hévizes karbonát kiválásai. (Carbonate precipitations of thermal water origin of Buda caves). Karszt és Barlang, 1990(2): 91-96.

Leél-Össy S., 1957 - A Budai-hegység barlangjai (The caves of Buda Hills). Földrajzi Értesíto, 6: 155167.

Leél-Őssy Sz., 2010 - Mineralogy and speleology of the Szemlö-hegy and Mátyás-hegy Caves with an introduction to the geology and speleology of the Rózsadomb area, Budapest, Hungary. Field guide for IMA 2010, 17 p.

Leél-Őssy Sz. \& Surányi G., 2003 - Peculiar hydrothermal caves in Budapest, Hungary. Acta Geol. Hung., 46(4): 407-436.

Melim L.A., Northup D.E., Spilde M.N., Jones B., Boston P.J. \& Bixby R.J., 2008 - Reticulated filaments in cave pool speleothems: microbe or mineral? Journal of Cave and Karst Studies, 70(3): $135-141$.

Müller P. \& Sárváry I., 1977 - Some aspects of development in Hungarian Speleology Theories during the last 10 years. Karszt és Barlang, Special Issue, 53-59.

Nádor A., 1992 - Mineralogy and stable isotope geochemistry of spelean carbonates from hydrothermal caves. Proceedings of Conference on the Karst and Cave Research, Jósvafö, 1991: 23-29.

Nagy S., 2008 - A Budai-hegység hidrotermás folyamatainak szerepe a Bátori-barlang és a Ferenc-hegyibarlang kialakulásában (The role of hydrothermal processes of Buda Hills in the genesis of Bátori Cave and Ferenc-hegy Cave). Manuscript, Eötvös University, Budapest, 110 p.
Palmer A.N., 2007 - Cave geology. Dayton, Cave books, $454 \mathrm{p}$.

Panoš V., 1960 - A Budai-hegység hévforrásos karsztja és különleges lerakódásai (The hydrothermal karst of Buda Hills and its peculiar precipitations). Hidrológiai Közlöny, 5: 391-395.

Scheuer Gy. \& Schweitzer F., 1988 - A Gerecse és a Budai-hegység édesvizi mészkő összlete (The freshwater limestone beds of Gerecse and Buda Hills). Földrajzi Tanulmányok, 20: 129 p.

Self C.A. \& Hill C., 2003 - How speleothems grow: An introduction to the ontogeny of cave minerals. Journal of Cave and Karst Studies, 65(2): 130-151.

Surányi G., 2005 - Módszerfejlesztés az ${ }^{234} U /{ }^{230} T h$ izotóparány mérésén alapuló uránsoros kormeghatározás terén (Uranium series dating of geological samples based on the determination of ${ }^{234} \mathrm{U} /{ }^{230}$ Th isotope ratio). PhD Thesis, Eötvös Loránd University, Budapest, 93 p.

Szanyi Gy., Bada G., Surányi G., Leél-Őssy Sz. \& Varga Zs., 2009 - Pleistocene uplift history of the Buda Hills (Hungary), using uranium-series dating of cave rafts. Földtani Közlöny, 139(4): 353-366.

Takácsné Bolner K., 1989 - Regional and special genetic marks on the Pál-völgy cave, the largest cave of thermal water origin in Hungary. Proceedings 10th International Congress of Speleology, Budapest, 819-822.

Takácsné Bolner K. \& Kraus S., 1989 - Results of the research of caves with thermal water origin. Karszt és Barlang, Special Issue, 31-38.

Wein Gy., 1977 - A Budai-hegység tektonikája. (Tectonics of the Buda Mts.) MÁFI, Spec. Publ. Budapest, $76 \mathrm{p}$. 